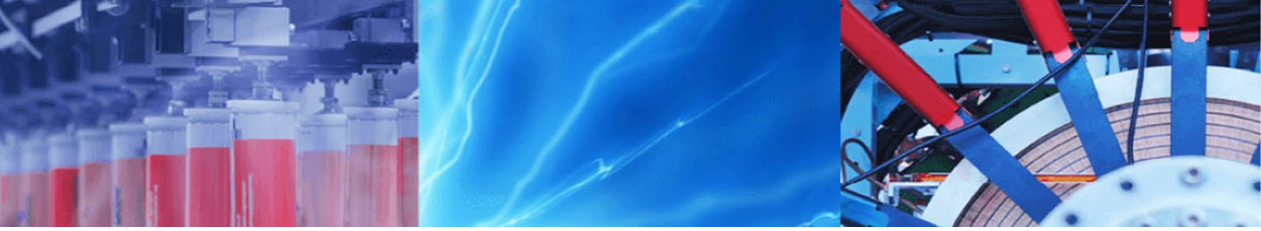

Research Article

\title{
Application of henna extract in minimizing surfactant adsorption on quartz sand in saline condition: A sacrificial agent approach
}

\author{
Mohd Syazwan Mohd Musa ${ }^{1}$ (1) $\cdot$ Wan Rosli Wan Sulaiman ${ }^{1} \cdot$ Zaiton Abdul Majid $^{2} \cdot$ Zulkifli Abdul Majid $^{3}$. \\ Ahmad Kamal Idris ${ }^{4} \cdot$ Kourosh Rajaei $^{1}$
}

(c) Springer Nature Switzerland AG 2019

\begin{abstract}
This study examined the adsorption ability of henna extract as an environment-friendly and accessible sacrificial agent. In this study, the Fourier transform infrared-attenuated total reflectance (FTIR-ATR) was used to characterized henna extract and quartz sand. The adsorption of the henna extract on quartz sand was executed using the ultraviolet-visible spectroscopy (UV-Vis). The current study also assesses the effects of salinity on the henna extract adsorption on quartz sand, and the mechanisms of the adsorption process were interpreted. Apart from that, the ability of henna extract in reducing the adsorption of surfactant in the presence of salts were recorded. The outcome demonstrated that henna extract adsorption on quartz sand increased with the increase of salinity concentrations. Note that the adsorption value increased from 3.14 to $8.11 \mathrm{mg} / \mathrm{g}$ in 0 and $50,000 \mathrm{mg} / \mathrm{L}$ of salinity, respectively. The main mechanisms involved in the adsorption process were hydrogen bond, hydrophobic interactions, and electrostatic attractions. A reduction of $46 \%$ of surfactant adsorption was observed. This was a profound decrease in the adsorption of surfactant in the presence of henna extract, suggesting a possibility to be utilized as a sacrificial agent in reducing surfactant adsorption.
\end{abstract}

Keywords Henna extract · Surfactant · Quartz sand · Adsorption · Salinity

\section{Introduction}

Surfactant flooding has been a vital part in enhanced oil recovery (EOR). This method is used to reduce the interfacial tension (IFT) of oil and water to improve the displacement efficiency through oil recovery [1]. Nevertheless, the surfactant adsorption on reservoir rock may impact the deprivation of the concentration of the surfactant, which may yield them less productive and competent [2].

The issues of the adsorption phenomenon of surfactants spark interests in lessening the adsorption of surfactant on reservoir rocks. Investigations on the implementation of similarly charged surfactant on the same surface charge of rock demonstrated that the anionic surfactant adsorption decreased on sandstone. The studies also concluded that the adsorption of cationic surfactant decreased on carbonate because of the repulsion of electrostatic between the adsorbent and the type of surfactants used $[3,4]$. However, because of the heterogeneity of the reservoir especially with the diversity of minerals including carbonate, aluminates, silicates, and various clays, it is hard to determine either anionic or cationic surfactants to be used.

Besides that, alkali as additives has been used to lower the adsorption of surfactants [5] and the mechanism of which was considered as changing the surface charge on the rock surface. However, the usage of alkali induces such

$\triangle$ Mohd Syazwan Mohd Musa, syazwan5597@yahoo.com | 'Department of Petroleum Engineering, School of Chemical and Energy Engineering, Faculty of Engineering, Universiti Teknologi Malaysia, 81310 Skudai, Johor Bahru, Malaysia. ${ }^{2}$ Department of Chemical, Faculty of Science, Universiti Teknologi Malaysia, 81310 Skudai, Johor Bahru, Malaysia. ${ }^{3}$ UTM-MPRC Institute for Oil and Gas, Universiti Teknologi Malaysia, 81310 Skudai, Johor Bahru, Malaysia. ${ }^{4}$ Department of Petroleum Engineering, Faculty of Geoscience and Petroleum Engineering, Universiti Teknologi PETRONAS, 32610 Bandar Seri Iskandar, Perak Darul Ridzuan, Malaysia. 
problems such as severe scaling in the near wellbore and production systems [6].

Following the research, the application of a sacrificial agent (SA) is deemed to be a promising method in reducing surfactant adsorption. The SA is a material that is injected to significantly inhibit or conceal all probable adsorption sites of the rock within the hydrocarbon formation. Weston et al. [7] have found that the formation of admicelles on the solid surface by the molecules of surfactant is the primary reason for adsorption to occur. The SA is strategically implemented to inhibit the development of these admicelles. ShamsiJazeyi et al. [8] in their work announced that polyelectrolyte had been proved to lessen adsorption of anionic surfactant on carbonates and clays minerals. In addition, surfactant adsorption was successfully reduced after the addition of the SA.

However, the materials used in reducing surfactant adsorption were chemicals which may be hazardous to living creatures and environment. Thus, materials that are eco-friendly, fewer impurities and simply accessible and are found from natural products, for instance, plant extracts that can act as an SA or inhibitor are being researched.

In this research, henna, a natural plant-based material was investigated as a potential SA. Henna is also known as Lawsonia inermis $\mathrm{L}$. This substance has been implemented as a corrosion inhibitor $[9,10]$ and Moslemizadeh et al. [11] revealed that henna extract can reduce the swelling of sodium bentonite better than exposing sodium bentonite to polyamine and potassium chloride due to its inhibitive capability. Apart from that, several researchers conducted inclusive studies on the effect of various parameters on the adsorption of surfactant, especially regarding the influence of added salts. Bera et al. [12] observed that the adsorption of surfactant magnifies with the increased of $\mathrm{NaCl}$ concentration while, ShamsiJazeyi et al. [8] found that by increasing the salinity of $\mathrm{Na}^{+}$ions, the adsorption of surfactant will simultaneously increase too. As indicated by Yekeen et al. [13], the degree of the adsorption of surfactant on reservoir rocks relies mostly on the electrolytes and the mineralogical composition of the rocks. Nevertheless, there is an absence of detailed knowledge on the application of henna extract as a SA in reducing surfactant adsorption in the vicinity of salts. Furthermore, the mechanisms of adsorption of the henna extract on quartz sand are still not well-understood by scholars.

This study was driven by the desire to comprehend the adsorption behavior of the henna extract on quartz sand and its ability in reducing surfactant adsorption with the influence of salinity. To reach this aim, the mechanisms of the adsorption process were analyzed. This study aimed to validate the notion that henna extract could be used as a $S A$ in minimalizing surfactant adsorption.

\section{Materials and methods}

\subsection{Materials}

Fresh henna leaves were gathered from henna trees in Johor, Malaysia. Methanol of 99.9\% (Acros Organics (USA)) was used as the solvent in methanolic extraction. The anionic surfactant, sodium dodecyl sulfate (SDS) of $98 \%$ purity weighing $288.38 \mathrm{~g} / \mathrm{mol}$ of molecular weight and manufactured by Fisher Chemical (UK) was used for the surfactant adsorption. Sodium chloride, $\mathrm{NaCl}$ ( $99.8 \%$ pure) provided by Vchem was used to study the effect of salinity, and quartz sand used in the experiment was collected in Desaru, Johor, Malaysia. Deionized water (DIW) was used for all experiments. All substances used in this study were of scientific quality and were used as acquired; in other words, devoid of added purifications.

\subsection{Preparation of henna powder}

The fresh leaves of henna were dried at room temperature and then grounded into powder using an electric blender. The henna powder was carefully packed in an airtight, BPA-free container and stored in room temperature until further used.

\subsection{Characterization of henna extract and quartz sand}

\subsubsection{FTIR-ATR analysis}

The FTIR-ATR was conducted using the Perkin Elmer FTIR Spectrometer (USA). Meanwhile, the functional groups of henna extract and quartz sand were identified using the spectrometer by observing the vibrational motion of bonds in the molecules. The spectra were measured in the range of $650-4000 \mathrm{~cm}^{-1}$ with a scan resolution of $2 \mathrm{~cm}^{-1}$. The FTIR data were documented in the transmittance mode. Then, the pattern of the spectrum was examined and compared to the IR absorption table to determine the functional groups encompassed in the samples.

\subsubsection{XRD analysis}

The quartz sand sample was further characterized by using the X-ray diffraction (XRD) in the continuous scanning mode on SmartLab X-Ray Diffractometer (Rigaku, Japan) operated at $40 \mathrm{kV}$ and a current of $30 \mathrm{~mA}$ with $\mathrm{Cu}-\mathrm{K}_{\beta}$ filter and $\mathrm{Cu}-\mathrm{K}_{\alpha}$ radiation source $(\lambda=0.154056 \mathrm{~nm})$. Particle size ought to be fine to attain a tolerable statistical representation of the components and their numerous diffracting 
crystal planes and to evade diffraction-related artifacts [14]. All the patterns were collected at room temperature with steps of $0.02^{\circ}$ in the $2 \theta$ range of $3^{\circ}-100^{\circ}$. The measurements were taken at room temperature with a scan rate of $8.2551^{\circ}$ per minute.

\subsection{Preparation of henna extract and surfactant solutions}

The solutions of henna extract were prepared in standard $250 \mathrm{ml}$ Erlenmeyer flasks. The henna extract was weighed and transferred into the flasks, and the DIW water was added to the required volume. Henna extract concentrations were prepared in the range of $3000-8000 \mathrm{mg} / \mathrm{L}$. It should be noted that the surfactant solutions were prepared similarly as henna extract solutions. Different concentrations of surfactant were prepared in the range of $1000-5000 \mathrm{mg} / \mathrm{L}$. The influence of salinity on henna extract adsorption was determined by preparing different henna extract solutions using $\mathrm{NaCl}$ at concentrations $10,000,30,000$, and 50,000 mg/L.

\subsection{Ultraviolet-visible spectroscopy (UV-Vis)}

UV-Vis measurement was performed to determine the maximum absorption wavelength of henna extract and surfactant. Besides that, it is also used to compute the concentration of henna extract and surfactant before and after adsorption using Shimadzu UV-1800 Spectrophotometer (Japan). The absorbance-wavelength between 200 and $800 \mathrm{~nm}$ was recorded. Quartz cuvettes were used as the vessel.

\subsection{Adsorption experiments}

The adsorption of the henna extract on quartz sand was determined using the depletion method. This method observed the differences between the concentrations of henna extract before and after adsorption on quartz sand. $6 \mathrm{~g}$ of quartz sand was mixed with $30 \mathrm{~mL}$ of henna extract solutions. The mixture was then agitated in a temperature controller shaker using IKA KS 3000 I control (USA) at $180 \mathrm{rpm}$ for $24 \mathrm{~h}$ at $25^{\circ} \mathrm{C}$ under atmospheric pressure to reach the state of equilibrium. They were then centrifuged using Rotofix 32A (Hettich Zentrifugen, Germany) at $4000 \mathrm{rpm}$ for $30 \mathrm{~min}$ to isolate the buoyant liquid. The concentrations of henna extract in the buoyant liquid was measured using a UV-Vis spectrophotometer. Adsorption amount at equilibrium time, $q_{e}(\mathrm{mg} / \mathrm{g})$, was calculated using Eq. (1). The same procedures were applied in calculating the adsorption of surfactant on quartz sand. Surfactant concentration of $2000 \mathrm{mg} / \mathrm{L}$ was employed to determine the surfactant adsorption on quartz sand. In evaluating henna extract performances in reducing surfactant adsorption on quartz sand, the solution mixtures of henna extract and quartz sand were filtered out, leaving only quartz sand behind. Then, $30 \mathrm{~mL}$ of surfactant solution (concentration of $2000 \mathrm{mg} / \mathrm{L}$ ) were mixed with the pre-treated quartz sand with henna extract solution. The mixtures were then left to reach the state of equilibrium for $24 \mathrm{~h}$ throughout which they were recurrently shaken in a temperature controller shaker at $180 \mathrm{rpm}$. After equilibrium was reached, the mixtures were centrifuged, and the buoyant liquid were examined using the UV-Vis spectrophotometer. The adsorption amount at equilibrium time, $q_{e}(\mathrm{mg} / \mathrm{g})$, was calculated using Eq. (1).

$q_{e}=\left(C_{o}-C_{e}\right) \times \frac{V}{m}$

where $q_{e}$ is the adsorption of henna extract and surfactant on quartz sand $(\mathrm{mg} / \mathrm{g}), C_{o}$ and $C_{e}$ are the henna extract and surfactant concentrations before and after the adsorption experiment, respectively ( $\mathrm{mg} / \mathrm{L}), V$ is the volume of henna extract and surfactant solutions added to the volumetric flask $(\mathrm{L})$, and $m$ is the total mass of the quartz sand added (g).

\section{Results and discussion}

\subsection{Characterization of henna extract and quartz sand}

\subsubsection{FTIR analysis}

The FTIR-ATR spectrum of henna extract was analyzed and depicted in Fig. 1, which demonstrates a wide absorption band at $3311 \mathrm{~cm}^{-1}$. Those bands were appointed to the vibration of the hydroxyl groups. A similar observation was reported in other studies $[9,15]$. Furthermore, the vibration of the aliphatic C-H group appeared at $2926 \mathrm{~cm}^{-1}$ and $2855 \mathrm{~cm}^{-1}$. The appearance of these functional groups was similar to the ones reported by other researchers [16]. The peaks at 1712 and $1632 \mathrm{~cm}^{-1}$ were assigned to the $C=0$ bond. A similar view was noted by Safie et al. [17]. The peaks at $1510,1449,1400$, and $1366 \mathrm{~cm}^{-1}$ were credited to the vibration of $\mathrm{C}=\mathrm{C}$ in the aromatic benzene rings. These peaks were also observed by several researchers $[9,18]$. The peaks at 1030 and $1064 \mathrm{~cm}^{-1}$ can be ascribed to the vibration of $\mathrm{C}-\mathrm{OH}$ of the phenolic group. Such conclusion was inspired by the trend that was perceived by Saadaoui et al. [19]. Phenolic compounds in the henna leaves are the core constituents that contributed to the popularity of henna in specific fields as mentioned above [20, 21]. Figure 2 shows the molecular structure of one of the phenolic compounds that are in the henna leaves-gallic acid [20]. 
Fig. 1 FTIR-ATR spectrum of henna extract

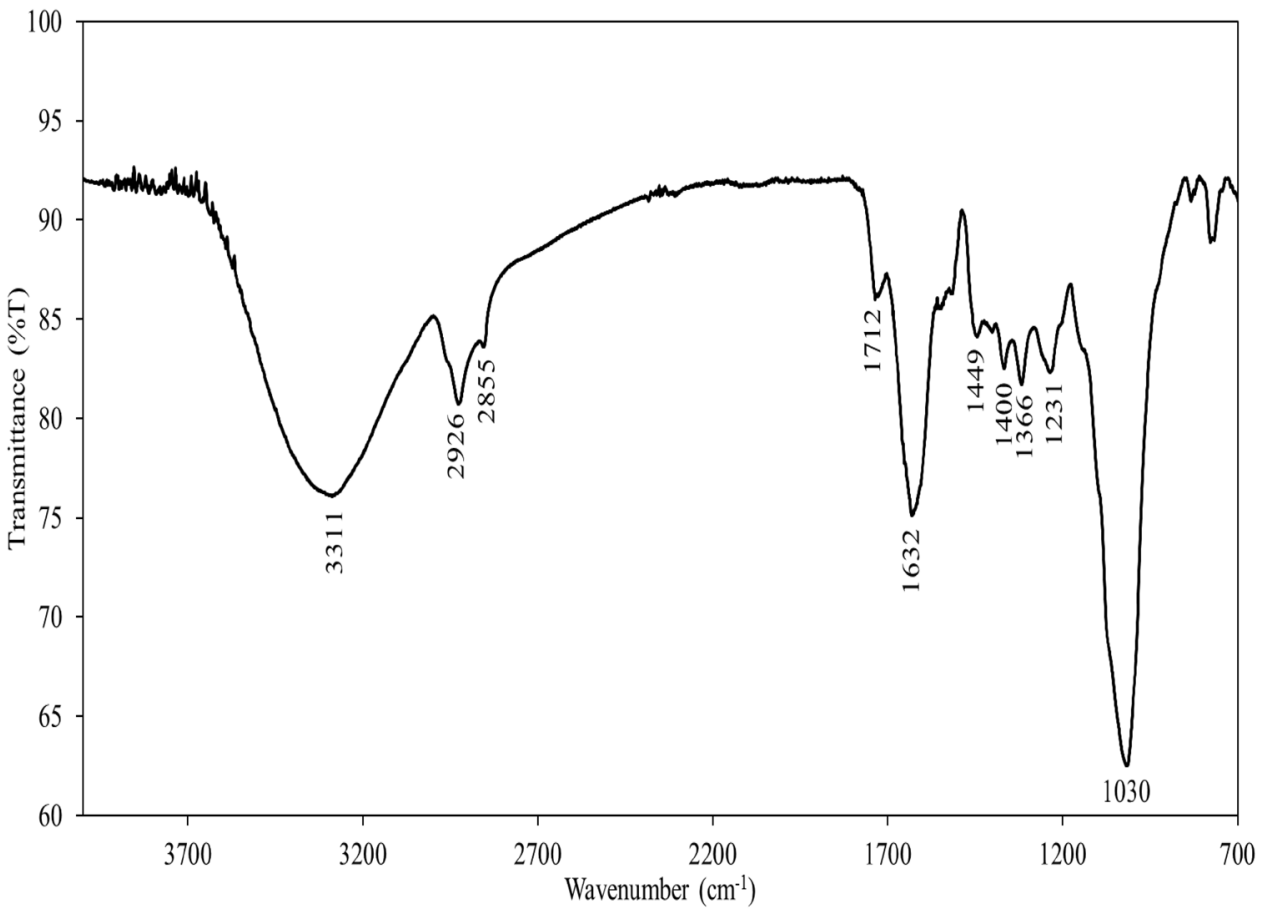

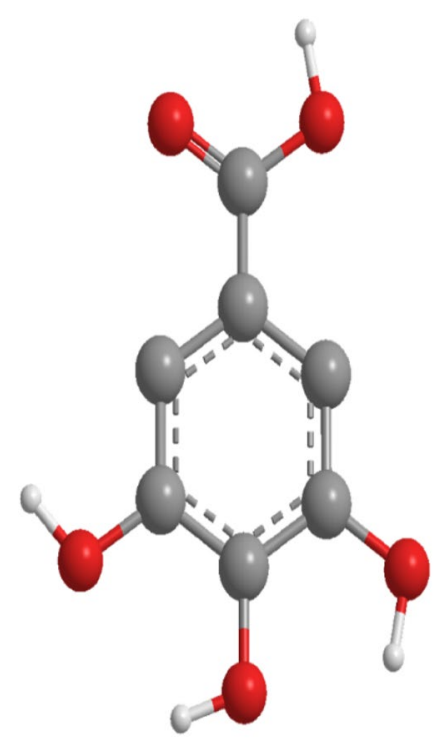

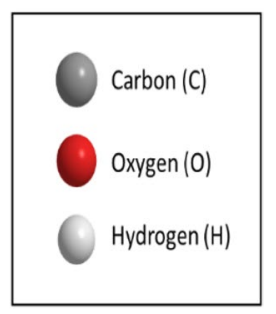

Fig. 2 Molecular structure of gallic acid

Figure 3 presents the infrared spectra of quartz sand. The band at $3286 \mathrm{~cm}^{-1}$ corresponded to the $\mathrm{OH}$ groups on the surface of quartz sand which made the silanol groups ( $\mathrm{SiOH}$ ). These observations were supported by Akl et al. [22] and Firoozmandan et al. [23]. The peak at $1632 \mathrm{~cm}^{-1}$ corresponding to the $\mathrm{OH}$ groups that made the silanol groups existed [24]. Vibrations of $\mathrm{Si}-\mathrm{O}$ and $\mathrm{Si}-\mathrm{O}-\mathrm{Si}$ is found at $1061 \mathrm{~cm}^{-1}$ as comparable to the ones reported by SöDerholm and Shang [25] and Liu et al. [26]. Hydroxyls functional group of silanol group was found at $778 \mathrm{~cm}^{-1}$. Identical analysis was demonstrated by Péré et al. [27] and Parida et al. [28].

\subsubsection{XRD analysis}

The XRD pattern of quartz sand is shown in Fig. 4. The diffraction peaks could be attributed to quartz sand and agreed with the standard data given in the ICDD card, 01-076-9282 for quartz sand. No impurity peaks were observed. Furthermore, the intensities of the diffraction peaks were high, and the peaks were sharp. This indicated that the sample were highly crystalline and consisted entirely of quartz sand.

\subsection{Ultraviolet-visible spectroscopy (UV-Vis)}

The wavelength of henna extract and surfactant were determined at $673 \mathrm{~nm}$ and $238 \mathrm{~nm}$ respectively, which corresponds to the maximum absorbance peak. Standard calibration curves were established by plotting absorbance against henna extract and surfactant concentrations to determine the final adsorption concentrations.

\subsection{Adsorption experiments}

\subsubsection{FTIR-ATR analysis on the adsorption of henna extract on quartz sand}

The FTIR spectrum of quartz sand before and after adsorption was observed and displayed in Fig. 5. After 
Fig. 3 FTIR-ATR spectrum of quartz sand

Fig. 4 XRD analysis of quartz sand
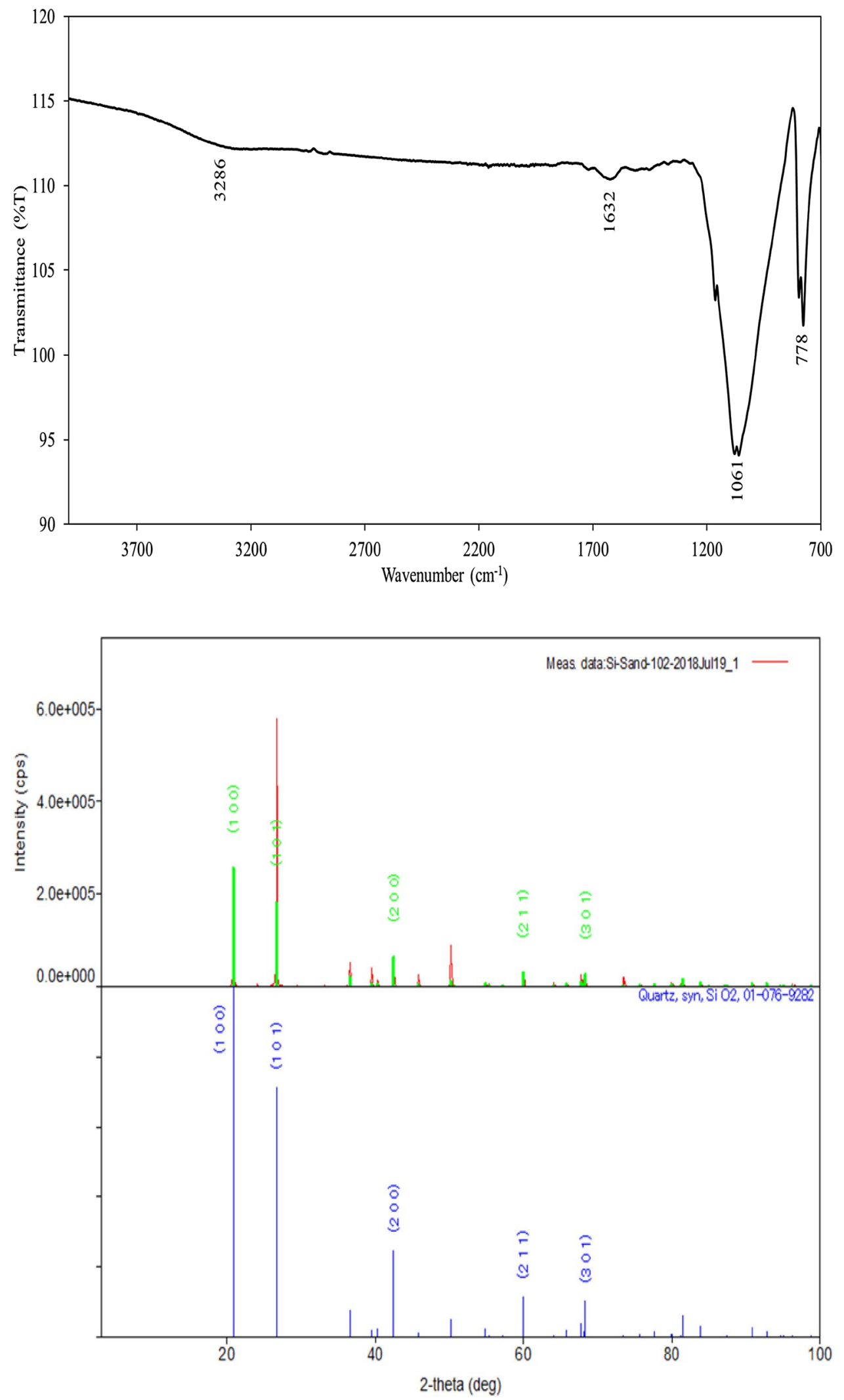
the adsorption of henna extract, there was a substantial change in the intensity of the adsorption peak at (a), signalling the interactions of the hydroxyl groups. Significant new adsorption peak was observed at (b) which belong to the aliphatic group of henna extract molecules. This was due to the interactions of hydrogen bond between henna extract and quartz sand molecules. The intensity of the characteristic peaks of carbonyl groups seen at (c) increased, after being adsorbed on quartz sand. This proposed that the carbonyl groups took part in the adsorption process. Apart from that, the intensity of the absorption peak that was observed at (d) owned by the aromatic rings, increased, signifying the interactions of aromatics with quartz sand molecules. The intensity of the absorption peak of phenolic groups observed at (e), increased and the range of the peak is sharper than before henna extract adsorption, proposing the interactions of phenolics and quartz sand molecules. At (f), there is an increased of the absorption peak that was due to the interactions of hydroxyl groups from quartz sand molecules with henna extract molecules.

\subsubsection{Effect of salinity on the adsorption of henna extract on quartz sand}

The adsorption of henna extract on quartz sand in the presence of salts was plotted against the concentration of henna extract. The effect of salinity at $0,10,000,30,000$,

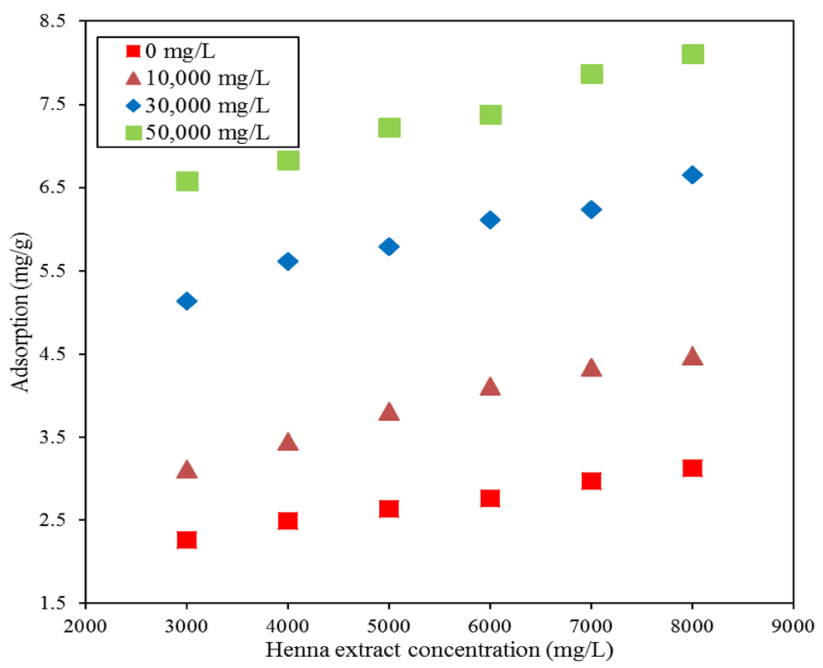

Fig. 6 Adsorption of henna extract on quartz sand at different salinities

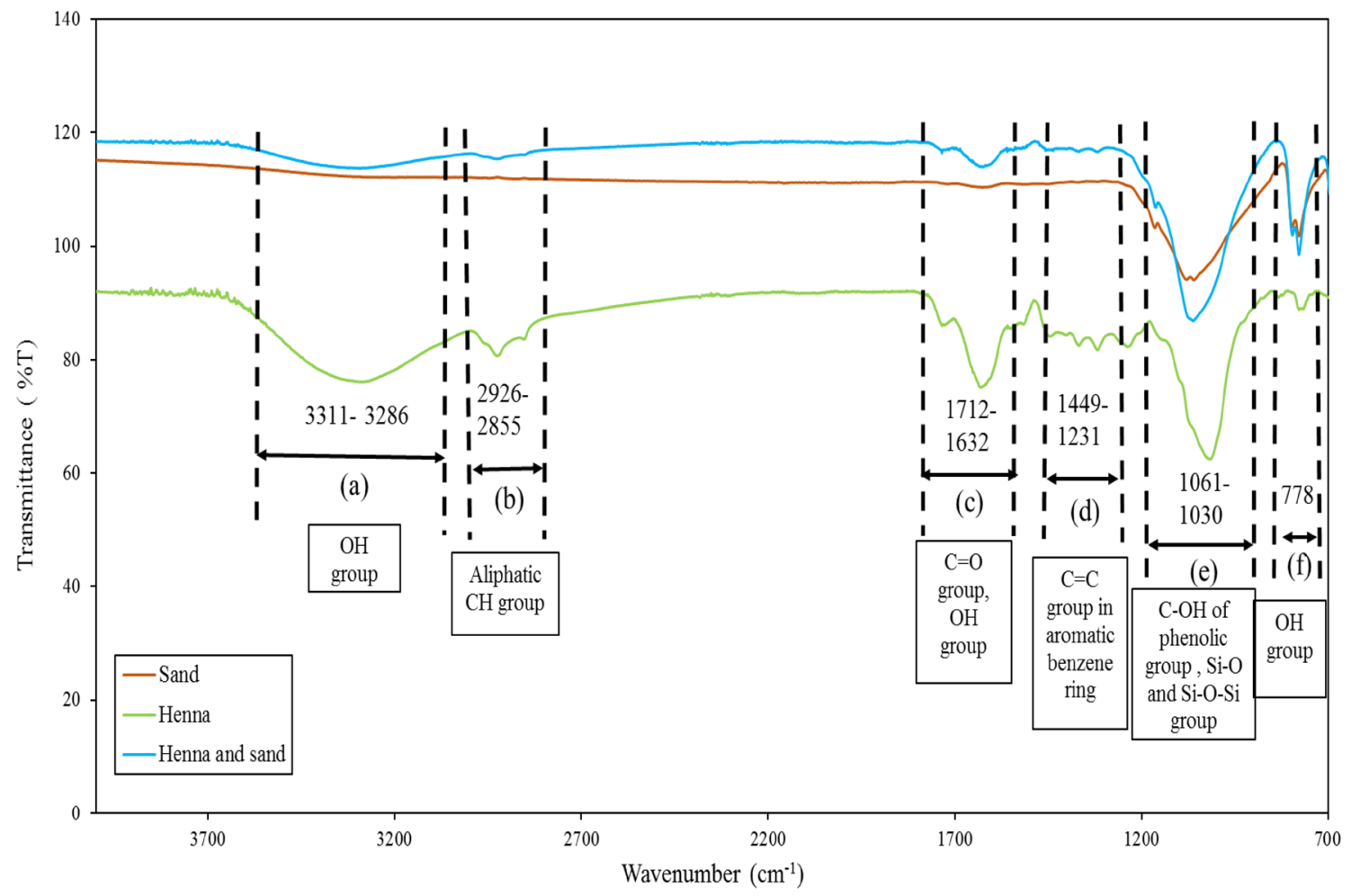

Fig. 5 FTIR-ATR analysis on the adsorption of henna extract on quartz sand 
and 50,000 mg/L were plotted and presented in Fig. 6. As shown in Fig. 6 , henna extract adsorption on quartz sand increased with the presence of sodium chloride $(\mathrm{NaCl})$.

The adsorption of henna extract on quartz sand increased from $3.14 \mathrm{mg} / \mathrm{g}$ without $\mathrm{NaCl}$ to $4.48 \mathrm{mg} / \mathrm{g}$ with the presence of $\mathrm{NaCl}$. The increment can be due to the presence of the positively charged cation $\left(\mathrm{Na}^{+}\right)$that increased the total electrostatic interactions among the henna extract molecules and the sodium ions. The carbonyl and hydroxyl groups in the henna extract molecules contain electronegative oxygen, and those groups were responsible for the increased adsorption. This is endorsed by Mckenzie et al. [29] who studied the adsorption behaviour of phenol in the presence of sodium ions. They concluded that the presence of sodium ions enhances adsorption. This principle is based on the electrostatic interactions between the positively charged cation $\left(\mathrm{Na}^{+}\right)$ and the negatively charged oxygen in the hydroxyl group of phenol. Figure 7 shows the mechanism of adsorption in the presence of sodium ions.

From the figures, it can be noted that the increasing salinity from 10,000 to 30,000 , and $50,000 \mathrm{mg} / \mathrm{L}$, improved the adsorption of henna extract on quartz sand. Adsorption of henna extract on quartz sand increased from 4.48 to 6.65 , and to $8.11 \mathrm{mg} / \mathrm{g}$ in the presence of $10,000,30,000$, and $50,000 \mathrm{mg} / \mathrm{L}$ of $\mathrm{NaCl}$, respectively. Comparable results were attained by Yekeen et al. [13], who also mentioned that the adsorption increased with the increase of the concentration of salt, in the presence of $\mathrm{NaCl}$ salts.

These observations can be credited to the increase in the number of cation $\left(\mathrm{Na}^{+}\right)$atoms on the quartz sand surface. The presence of salt encourages adsorption by increasing the presence of positive charges on the surface so that the negatively-charged oxygen can bind on the
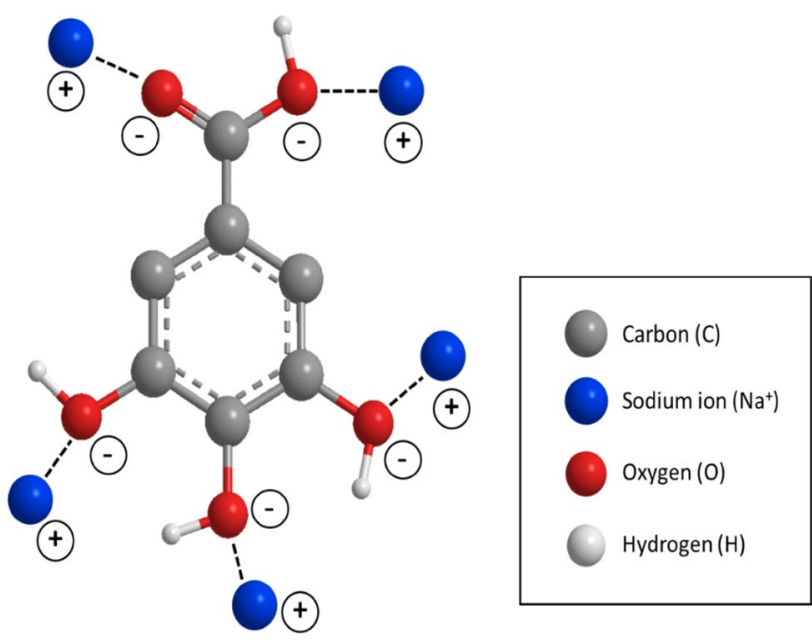

Fig. 7 Electrostatic attraction in the presence of sodium ions Modified from McKenzie et al. [29] cations. Furthermore, the presence of the aromatic rings in phenolic compounds enhances the adsorption due to the negatively charged rings $[30,31]$. This promotes the interaction of cation/ $\pi$ between the $\mathrm{Na}^{+}$and the rings [32, 33]. Figure 8 demonstrates the interaction of cation/ $\pi$.

Besides electrostatic attraction between the positivelycharged cation and the negatively-charged portion of henna extract molecules, $\mathrm{Na}^{+}$is beneficial in forming bridges of cation between the negatively charged portion of the molecules of henna extract and the negatively charged quartz sand layer [34, 35]. Moreover, the cation bridges can be formed between the henna extract molecules themselves. This will further compress the molecules further, allowing more henna extract molecules to be adsorbed. The neutralizing bridges between the henna extract molecules and the negatively charged quartz sand layer on the surface led to the indirect adsorption. Figures 9 and 10 demonstrate the schematic diagrams of the effect of salt bridges.

In addition, the effect of salinity on henna extract adsorption on quartz sand can be attributed to the positive cations $\left(\mathrm{Na}^{+}\right)$. These cations were attracted to the permanently negative- charged sites (silanol sites, $\mathrm{Si}-\mathrm{O}$ ) on quartz sand surfaces [36]. Therefore, an increase in the adsorption of henna extract with increasing salinity implies that increasing salinity reduces the negativelycharged sites on the quartz sand surface, increasing henna extract adsorption [37]. Then, the negatively-charged groups from henna extract molecules can bind more to these positively charged surface on quartz sand due to the electrostatic forces.

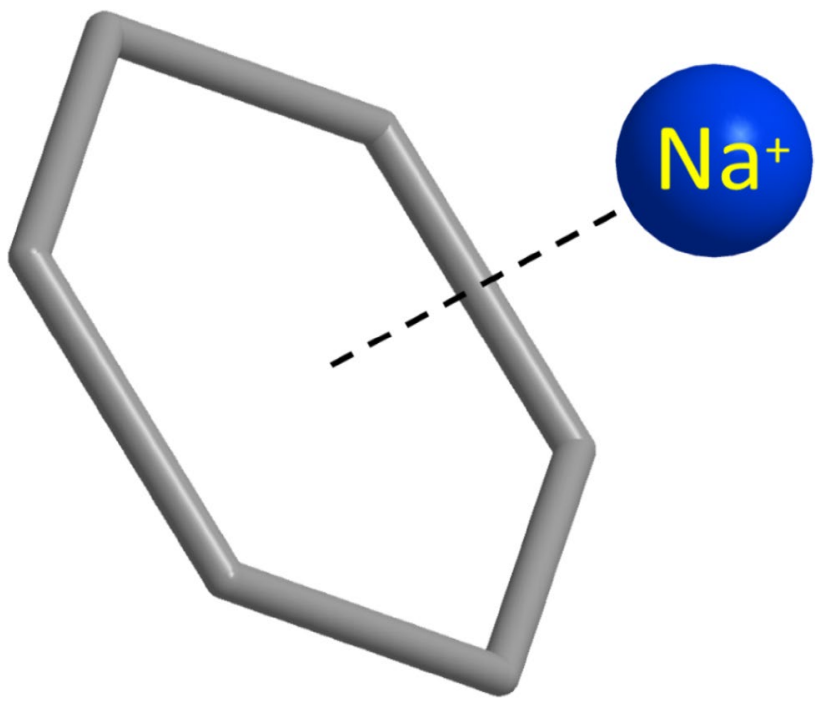

Fig. 8 Cation- $\Pi$ interaction between sodium ion and aromatic ring Modified from Kumar et al. [33] 

bridges due to the presence $\mathrm{Na}^{+}$ions between the quartz sand surface and henna extract molecules Modified from Yu et al. [35]
Fig. 9 Formation of salt
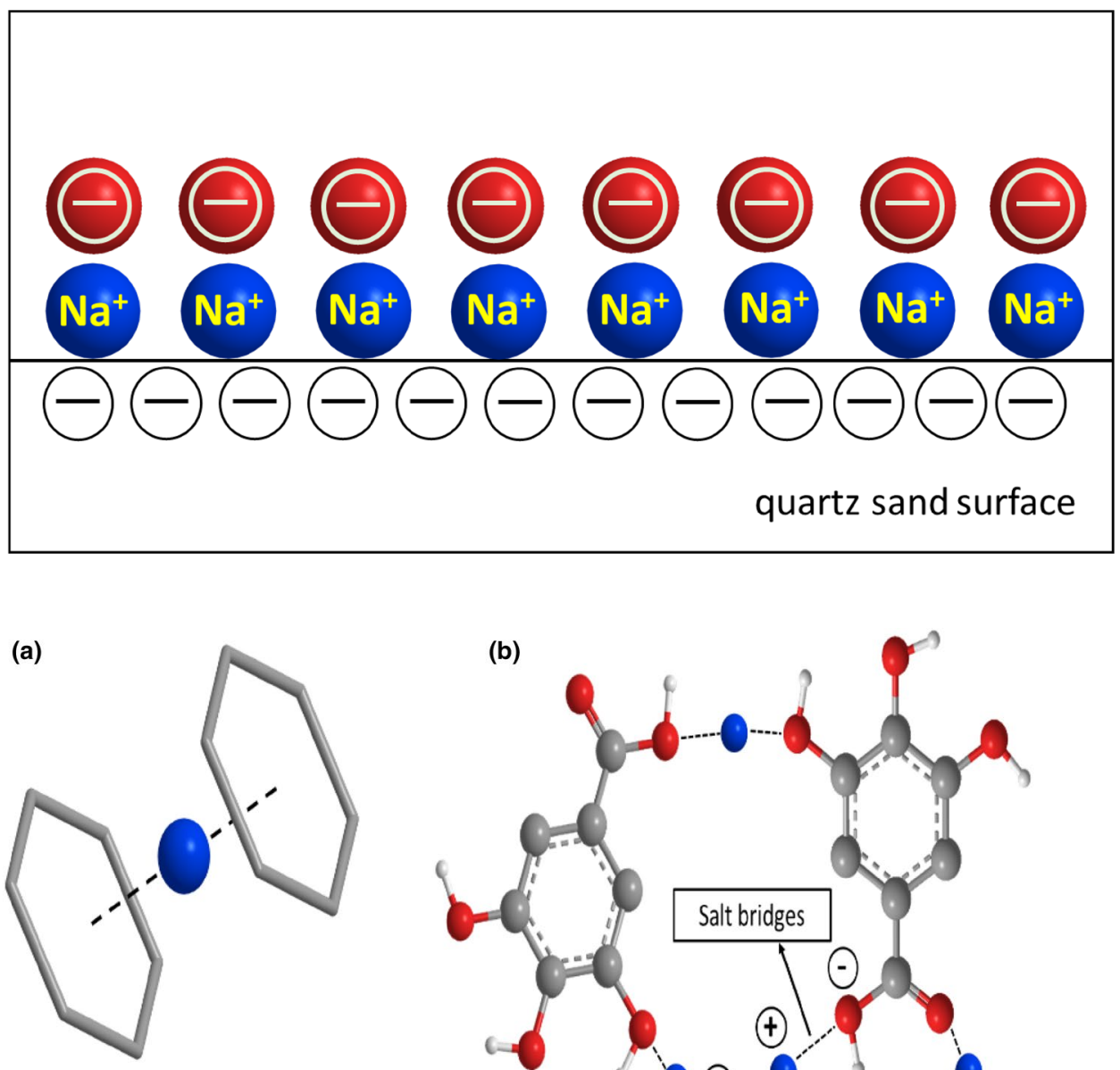

Fig. 10 Formation of salt bridges due to the presence $\mathrm{Na}^{+}$ions (a) between aromatic rings and (b) among henna extract molecules Modified from Yu et al. [35]

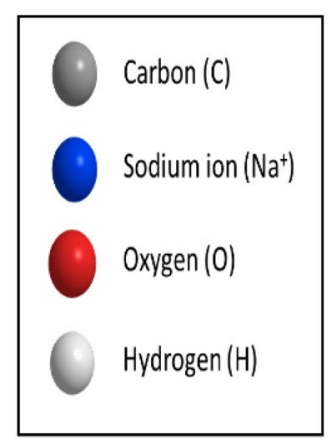

solutions. These remarks are due to cation being adsorbed on the negatively-charged quartz sand surface, producing additional positive sites for the anionic surfactant to adsorb [38]. Furthermore, the added salt in the solutions made the EDL and zeta potential of the quartz sand surface to compress, allowing more surfactant to be adsorbed $[39,40]$.

\subsubsection{Influence of salinity on the adsorption of surfactant on quartz sand with the presence of henna extract}

An evaluation of the adsorption of surfactant on pretreated quartz sand with henna extract in the presence sand increased from 1.57 to $5.16 \mathrm{mg} / \mathrm{g}$ from DIW to saline 


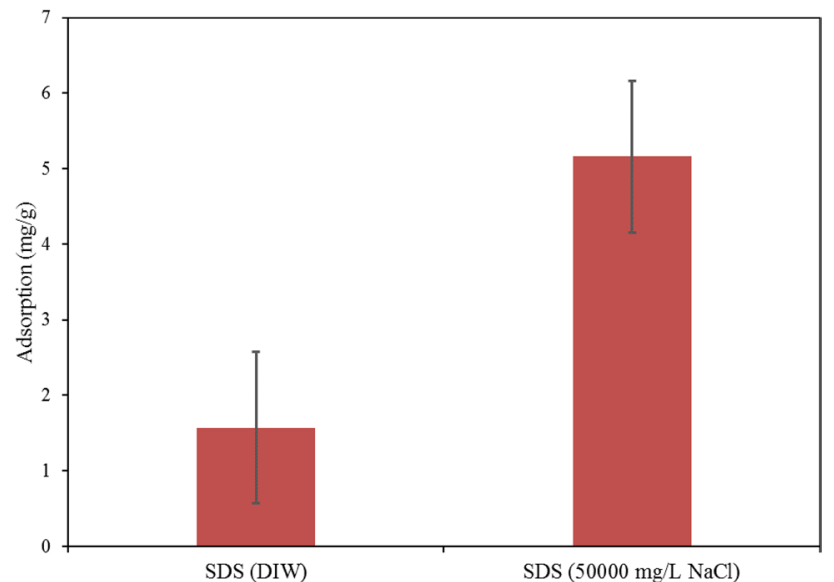

Fig. 11 Surfactant adsorption with the effect of salinity

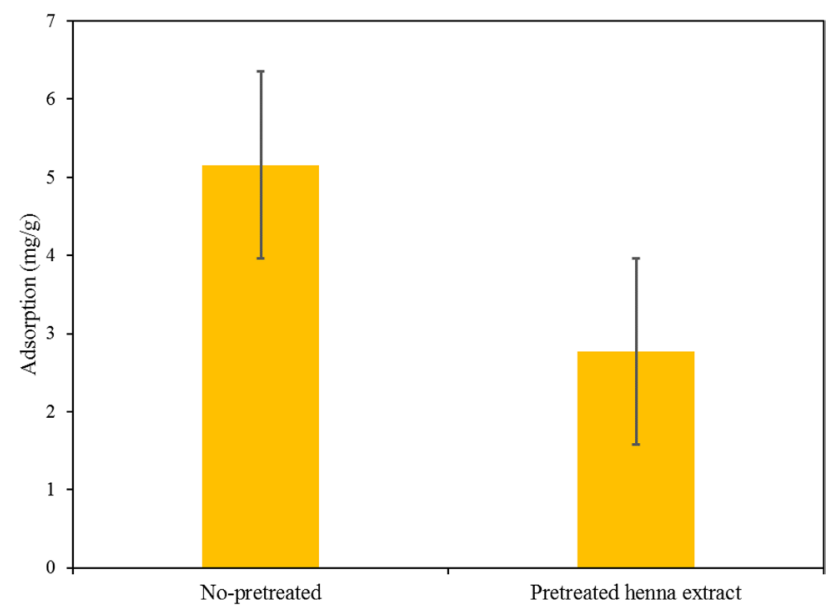

Fig. 12 Henna extract performances on the reduction of the surfactant adsorption in the presence of salts $(50,000 \mathrm{mg} / \mathrm{L} \mathrm{NaCl})$

of salts was conducted. The salinity of $50,000 \mathrm{mg} / \mathrm{L}$ was chosen due to the highest adsorption capacity of henna extract on quartz sand. Based on the result of the CMC (not shown), a surfactant concentration of $2000 \mathrm{mg} / \mathrm{L}$ was used to determine the capability of henna extract in reducing surfactant adsorption. Meanwhile, for the henna extract concentration, $8000 \mathrm{mg} / \mathrm{L}$ of surfactant concentration was chosen. Figure 12 shows the surfactant adsorption data.

It is shown that the adsorption of surfactant on pretreated quartz sand was reduced in the presence of $\mathrm{NaCl}$ from $5.16 \mathrm{mg} / \mathrm{g}$ to $2.77 \mathrm{mg} / \mathrm{g}$. The reduction of surfactant adsorption was about $46 \%$. The reduced surfactant adsorption on the pre-treated quartz sand with henna extract can be attributed to the presence of cation $\left(\mathrm{Na}^{+}\right)$. Based on the mechanism discussed above, the cation allows the henna extract molecules to adsorb more, providing less binding option for surfactant molecules to bind to the surface of quartz sand and henna extract molecules. This made the surfactant molecules free to move, reducing surfactant adsorption.

\section{Conclusion}

The existence of the functional groups in henna extract, hydroxyls, carbonyls, phenolics, aromatic benzene ring, and aliphatic carbon-hydrogen groups allow for the adsorption process. Quartz sand was characterized and used as an adsorbent to investigate the effect of salinity on henna extract adsorption on quartz sand and to evaluate the performances of henna extract as a SA in reducing surfactant adsorption. The presence of salt improved the adsorption of henna extract on quartz sand, and increasing the salinity further improved the adsorption. Meanwhile, the electrostatic interactions played a substantial role as perceived from the role of a cation such as sodium $\left(\mathrm{Na}^{+}\right)$. The study of surfactant adsorption was done to determine the efficiency of the henna extract adsorption. This was determined by analyzing the results of before-and-after adsorption values of surfactant adsorption on quartz sand. The salinity demonstrated that the surfactant adsorption exhibited identical traits of adsorption with the henna extract adsorption process. This follows that the adsorption of surfactant on quartz sand increased in the existence of salts rather than in the absence of salts. Moreover, the adsorption of surfactant on pre-treated quartz sand with henna extract in the presence of salts managed to be reduced. It was observed that there was a $46 \%$ reduction, caused by the electrostatic attractions between henna extract and quartz sand. The surface of quartz sand was covered with henna extract molecules, inhibiting the surfactant molecules from being adsorbed. Hydrogen bond, electrostatic attraction, and hydrophobic interactions played a significant role in the mechanism of adsorption between henna extract and quartz sand. This study proved that henna extract has the potential to be a SA in reducing surfactant adsorption in the presence of salts.

Acknowledgements The authors wish to thank the Ministry of Higher Education (MOHE), Malaysia, and Universiti Teknologi Malaysia for assisting this research through Fundamental Research Grant Scheme (R.J130000.7846.4F931) and Research University Grant (12429).

\section{Compliance with ethical standards}

Conflict of interest On behalf of all authors, the corresponding author states that there is no conflict of interest. 


\section{References}

1. Olajire AA (2014) Review of ASP EOR (alkaline surfactant polymer enhanced oil recovery) technology in the petroleum industry: prospects and challenges. Energy 77:963-982. https://doi. org/10.1016/j.energy.2014.09.005

2. Barati A, Najafi A, Daryasafar A, Nadali P, Moslehi H (2016) Adsorption of a new nonionic surfactant on carbonate minerals in enhanced oil recovery: experimental and modeling study. Chem Eng Res Des 105:55-63. https://doi.org/10.1016/j.cherd .2015.10.047

3. Zhang R, Somasundaran P (2006) Advances in adsorption of surfactants and their mixtures at solid/solution interfaces. Adv Colloid Interface Sci 123-126:213-229. https://doi.org/10.1016/j. cis.2006.07.004

4. Ishiguro M, Koopal LK (2016) Surfactant adsorption to soil components and soils. Adv Colloid Interface Sci 231:59-102. https:// doi.org/10.1016/j.cis.2016.01.006

5. Dang CTQ, Chen ZJ, Nguyen NTB, Bae W, Phung TH (2013) Development of isotherm polymer/surfactant adsorption models in chemical flooding. SPE Asia Pacific Oil Gas Conf Exhib. https:// doi.org/10.2118/147872-ms

6. Tay A, Oukhemanou F, Wartenberg N, Moreau P, Guillon V, Delbos A (2015) Adsorption inhibitors : a new route to mitigate adsorption in chemical. Society of Petroleum Engineers, Oslo

7. Weston JS, Harwell JH, Shiau BJ, Kabir M (2014) Disrupting admicelle formation and preventing surfactant adsorption on metal oxide surfaces using sacrificial polyelectrolytes. Langmuir 30:6384-6388. https://doi.org/10.1021/la501074x

8. ShamsiJazeyi H, Verduzco R, Hirasaki GJ (2014) Reducing adsorption of anionic surfactant for enhanced oil recovery: part II. Applied aspects. Colloids Surfaces A Physicochem Eng Asp 453:168-175. https://doi.org/10.1016/j.colsurfa.2014.02.021

9. Rajendran S, Agasta M, Devi R, Devi B, Rajam K, Jayasundari J (2009) Corrosion inhibition by an aqueous extract of henna leaves (Lawsonia Inermis L). Zaštita Mater 50:77-84

10. Chaudhari HG, Vashi RT (2016) The study of henna leaves extract as green corrosion for mild steel in acetic acid. J Fundam Appl Sci 8(2):280-296

11. Moslemizadeh A, Shadizadeh SR, Moomenie M (2015) Experimental investigation of the effect of henna extract on the swelling of sodium bentonite in aqueous solution. Appl Clay Sci 105-106:78-88. https://doi.org/10.1016/j.clay.2014.12.025

12. Bera A, Kumar T, Ojha K, Mandal A (2013) Adsorption of surfactants on sand surface in enhanced oil recovery: isotherms, kinetics and thermodynamic studies. Appl Surf Sci 284:87-99. https://doi.org/10.1016/j.apsusc.2013.07.029

13. Yekeen N, Manan MA, Idris AK, Samin AM (2017) Influence of surfactant and electrolyte concentrations on surfactant Adsorption and foaming characteristics. J Pet Sci Eng. https://doi. org/10.1016/j.petrol.2016.11.018

14. Singh V, Agrawal HM (2012) Qualitative soil mineral analysis by EDXRF, XRD and AAS probes. Radiat Phys Chem 81:1796-1803. https://doi.org/10.1016/j.radphyschem.2012.07.002

15. Mounaouer B, Wali A, Fourti O, Hassen A (2014) Henna wood as an adsorptive material for bentazon. Afr J Biotechnol 13:35973606. https://doi.org/10.5897/AJB2013.13000

16. Ebrahimi I, Gashti MP (2015) Extraction of polyphenolic dyes from henna, pomegranate rind, and Pterocarya fraxinifolia for nylon 6 dyeing. Color Technol 132:162-176. https://doi. org/10.1111/cote.12204

17. Safie NE, Ludin N, Su'ait MS, Hamid NH, Sepeai S, Ibrahim MA, Mat MAT (2015) Preliminary study of natural pigments photochemical properties of Curcuma longa L. and Lawsonia inermis L. Malaysian J Anal Sci 19:1243-1249
18. Hamdy A, El-Gendy NS (2013) Thermodynamic, adsorption and electrochemical studies for corrosion inhibition of carbon steel by henna extract in acid medium. Egypt J Pet 22:17-25. https://doi.org/10.1016/j.ejpe.2012.06.002

19. Saadaoui S, Youssef MA, Karoui M, Gharbi R, Smecca E, Strano V, Mirabella S, Alberti A, Puglisi RA (2017) Performance of natural-dye-sensitized solar cells by $\mathrm{ZnO}$ nanorod and nanowall enhanced photoelectrodes. Beilstein J Nanotechnol 8:287295. https://doi.org/10.3762/bjnano.8.31

20. Ostovari A, Hoseinieh SM, Peikari M, Shadizadeh SR, Hashemi SJ (2009) Corrosion inhibition of mild steel in $1 \mathrm{M} \mathrm{HCl}$ solution by henna extract: a comparative study of the inhibition by henna and its constituents (lawsone, gallic acid, a-Dglucose and tannic acid). Corros Sci 51:1935-1949. https:// doi.org/10.1016/j.corsci.2009.05.024

21. Rahmat A, Edrini S, Ismail P, Hin TYY, Bakar MF (2006) Chemical constituents, antioxidant activity and cytotoxic effects of essential oil from strobilanthes crispus and lawsonia inermis. J Biol Sci 6:1005-1010. https://doi.org/10.3923/ jbs.2006.1005.1010

22. Akl MA, Aly HF, Soliman HMA, Abd-ElRahman AME, AbdElhamid Al (2013) Preparation and characterization of silica nanoparticles by wet mechanical attrition of white and yellow sand. J Nanomed Nanotechnol. https://doi.org/10.4172/21577439.1000183

23. Firoozmandan M, Moghaddas J, Yasrebi N (2016) Performance of water glass-based silica aerogel for adsorption of phenol from aqueous solution. J Sol-Gel Sci Technol 79:67-75. https://doi. org/10.1007/s10971-016-4007-2

24. Shewale PM, Rao AV, Rao AP (2008) Effect of different trimethyl silylating agents on the hydrophobic and physical properties of silica aerogels. Appl Surf Sci 254:6902-6907. https://doi. org/10.1016/j.apsusc.2008.04.109

25. SöDerholm KJM, Shang SW (1993) Molecular orientation of silane at the surface of colloidal silica. J Dent Res 72:1050-1054. https://doi.org/10.1177/00220345930720061001

26. Liu H, Sha W, Cooper AT, Fan M (2009) Preparation and characterization of a novel silica aerogel as adsorbent for toxic organic compounds. Coll Surf A Physicochem Eng ASP 347:38-44. https ://doi.org/10.1016/j.colsurfa.2008.11.033

27. Péré $E$, Cardy H, Cairon O, Simon M, Lacombe S (2001) Quantitative assessment of organic compounds adsorbed on silica gel by FTIR and UV-VIS spectroscopies: the contribution of diffuse reflectance spectroscopy. Vib Spectrosc 25:163-175. https://doi. org/10.1016/S0924-2031(00)00113-2

28. Parida SK, Dash S, Patel S, Mishra BK (2006) Adsorption of organic molecules on silica surface. Adv Coll Interface Sci 121:77-110. https://doi.org/10.1016/j.cis.2006.05.028

29. Mckenzie ME, Goyal S, Lee SH, Park H, Savoy E, Rammohan AR, Mauro JC, Kim H, Min K, Cho E (2016) Adhesion of organic molecules on silica surfaces: a density functional theory study. J Phys Chem C 121:392-401. https://doi.org/10.1021/acs.jpcc.6b10394

30. Anjana R, Vaishnavi MK, Sherlin D, Kumar SP, Naveen K, Kanth PS, Sekar K (2012) Aromatic-aromatic interactions in structures of proteins and protein-DNA complexes: a study based on orientation and distance. Bioinformation 8:1220-1224. https://doi. org/10.6026/97320630081220

31. Rimola A, Civalleri B, Ugliengo P (2010) Physisorption of aromatic organic contaminants at the surface of hydrophobic/ hydrophilic silica geosorbents: a B3LYP-D modeling study. Phys Chem Chem Phys 12:6357-6366. https://doi.org/10.1039/c0000 09d

32. Dougherty DA (2013) The cation- $\pi$ interaction. Acc Chem Res 46:885-893. https://doi.org/10.1021/ar300265y

33. Kumar K, Woo SM, Siu T, Cortopassi WA, Duarte F, Paton RS (2018) Cation- $\pi$ interactions in protein-ligand binding: theory 
and data-mining reveal different roles for lysine and arginine. Chem Sci 9:2655-2665. https://doi.org/10.1039/c7sc04905f

34. Saeki K, Kunito T (2010) Adsorptions of DNA molecules by soils and variable-charged soil constituents. Appl Microbiol Microb Biotechnol 1:188-195

35. Yu WH, Li N, Tong DS, Zhou CH, Lin CX, Xu CY (2013) Adsorption of proteins and nucleic acids on clay minerals and their interactions: a review. Appl Clay Sci 80-81:443-452. https://doi. org/10.1016/j.clay.2013.06.003

36. Jiang $M$, Jin X, Lu X, Chen Z (2010) Adsorption of Pb(II), Cd (II), Ni (II) and Cu (II) onto natural kaolinite clay. Des 252:33-39. https ://doi.org/10.1016/j.desal.2009.11.005

37. Unuabonah El, Adebowale KO, Olu-Owolabi BI, Yang LZ, Kong LX (2008) Adsorption of Pb(II) and Cd (II) from aqueous solutions onto sodium tetraborate-modified Kaolinite clay: equilibrium and thermodynamic studies. Hydrometallurgy 93:1-9. https:// doi.org/10.1016/j.hydromet.2008.02.009
38. Malekbala MR, Khan MA, Hosseini S, Abdullah LC, Choong TSY (2015) Adsorption/desorption of cationic dye on surfactant modified mesoporous carbon coated monolith: equilibrium, kinetic and thermodynamic studies. J Ind Eng Chem 21:369377. https://doi.org/10.1016/j.jiec.2014.02.047

39. Muherei MA, Junin R (2007) Effect of electrolyte on synergism of anionic-nonionic surfactant mixture. J Appl Sci 7(10):1362-1371

40. Gogoi SB (2011) Adsorption-desorption of surfactant for enhanced oil recovery. Transp Porous Media 90:589-604. https ://doi.org/10.1007/s11242-011-9805-y

Publisher's Note Springer Nature remains neutral with regard to jurisdictional claims in published maps and institutional affiliations. 